\title{
Oxygen sensing decoded: a Nobel concept in biology
}

\author{
Arjan W. Griffioen ${ }^{1}$ - Joyce Bischoff ${ }^{2}$
}

Published online: 31 October 2019

(c) Springer Nature B.V. 2019

\begin{abstract}
Oxygen is essential to most organisms as it is a necessity for aerobic metabolism and energy production. Too much or too little oxygen can be deadly, such that mechanisms for fast and titrated response to changing oxygen levels are crucial. These mechanisms have evolved from the studies of Gregg L. Semenza, William G. Kaelin and Peter J. Ratcliffe. It is through the work of their three laboratories, performed in the 1990s, that the cellular oxygen sensing mechanisms have been decoded. Their discoveries have had major impact for innovation in medicine, especially in the field of angiogenesis research, where oxygen sensing and its consequences have led to enhanced insight in vascular development and strategies for combating angiogenic diseases. On October 7, the Nobel Assembly in Stockholm announced at the Karolinska Institute that the Nobel Prize for Medicine 2019 is jointly awarded to these three scientists for their seminal discoveries on how cells sense and respond to oxygen.
\end{abstract}

Keywords Oxygen sensing · Angiogenesis · Erythropoietin · Hypoxia Inducible Factor (HIF) $\cdot$ Nobel prize $\cdot$ Vasculature

The element oxygen was discovered in the eighteenth century by Joseph Priestly and Karl Wilhelm Scheele, and possibly by others, who discovered that oxygen (which they called fire air) was important for combustion and burning of materials. The presence of oxygen in the atmosphere is the result of photosynthesis by living organisms, mainly the marine cyanobacteria. Roughly one-fifth of outside air is oxygen, and living organisms have adapted to its availability. When access to oxygen changes, cells have to react to it, as too low or too high oxygen pressure presents major challenges. At high altitudes, where air contains less oxygen, the secretion of the hormone erythropoietin by the kidneys is stimulated, resulting in the production of more red blood cells, thereby alleviating the shortage of oxygen. Without trying to be exhaustive, the sequence of discoveries

Arjan W. Griffioen

aw.griffioen@vumc.nl

$\triangle$ Joyce Bischoff

joyce.bischoff@childrens.harvard.edu

1 Angiogenesis Laboratory, Department of Medical Oncology, Amsterdam UMC, Cancer Center Amsterdam, 1081 HV Amsterdam, The Netherlands

2 Karp Family Research Labs, Vascular Biology Program and Department of Surgery, Boston Children's Hospital and Harvard Medical School, 300 Longwood Ave, Boston, MA 02115, USA leading to the delineation of oxygen sensing mechanisms is as follows. Gregg Semenza and his team were investigating the mechanism behind the enhanced production of erythropoietin (EPO) and found a protein that they called hypoxia inducible factor (HIF), which binds at a site in the EPO gene enhancer that is required for hypoxic activation of transcription [1]. Later, HIF was identified as a complex of HIF-1 $\alpha$ and aryl hydrocarbon receptor nuclear translocator (ARNT or HIF-1 $\beta$ ) [2, 3]. Thus, HIF acts as a transcription factor for EPO, regulating its mRNA transcript expression. Subsequently, Semenza and also Peter Ratcliffe and his team discovered that the gene for EPO is not the only one that is sensitive to oxygen pressure. Many genes were found to be regulated by oxygen, among which was vascular endothelial cell growth factor (VEGF) [4]. VEGF is a central driving force in the formation of new vasculature, which in turn increases oxygenation, and so VEGF expression is exquisitely adapted to oxygen levels [5]. All of these studies demonstrated that HIF is a universal oxygen sensor that can rapidly induce cells to cope with oxygen shortage. Bill Kaelin and his colleagues discovered the mechanisms at play under normal oxygen: HIF is rapidly degraded to shut off low oxygen-responsive genes. They were investigating a hereditary type of cancer, called Von Hippel-Lindau (VHL) syndrome. This disease is characterized by mutations in the VHL gene, a tumor suppressor gene [6,7], and the formation 
of tumors throughout the body, often in the kidneys. These tumors were observed to be heavily vascularized and expression of HIF and VEGF, often also EPO, was high in these tumors [8]. Kaelin and his team hypothesized a defect in the oxygen sensing system of VHL tumor cells, which led to the discovery of the regulation of HIF by VHL protein $[9,10]$. While under normal conditions VHL protein forms a complex that is involved in degradation of HIF through the protostome [10], mutations in the VHL gene prevent its normal function, resulting in high HIF expression even in the presence of high oxygen levels. This results in unlimited expression of HIF target genes, including VEGF, which in the latter case contributes to excessive angiogenesis.

The three 2019 Nobel Prize in Medicine recipients opened an entire field with far-reaching implications by discovering how low oxygen stabilizes HIF so that it can activate transcription of VEGF-A and other critical genes. For many, their work has been instrumental for enhanced insight into settings of pathological angiogenesis, such as in atherosclerosis [11], rheumatoid arthritis as well as in the fields of ophthalmology (age-related macular degeneration) [12], gynecology (endometriosis and adenomyosis) [13] and cancer. In particular for cancer, dozens of drugs have been developed to inhibit angiogenesis, either directly or indirectly targeting oxygen sensing molecules [14, 15] or by targeting angiogenesis by other mechanisms [16, 17].

We are indebted to the exceptional work of Gregg L. Semenza, William G. Kaelin and Peter J. Ratcliffe. We congratulate them with the Nobel Prize for Medicine 2019.

\section{References}

1. Wang GL, Semenza GL (1993) General involvement of hypoxiainducible factor 1 in transcriptional response to hypoxia. Proc Natl Acad Sci USA 90:4304-4308

2. Wang GL, Jiang BH, Rue EA, Semenza GL (1995) Hypoxiainducible factor 1 is a basic-helix-loop-helix-PAS heterodimer regulated by cellular O2 tension. Proc Natl Acad Sci USA 92:5510-5514

3. Semenza GL, Rue EA, Iyer NV, Pang MG, Kearns WG (1996) Assignment of the hypoxia-inducible factor 1alpha gene to a region of conserved synteny on mouse chromosome 12 and human chromosome 14q. Genomics 34:437-439

4. Maxwell PH, Dachs GU, Gleadle JM, Nicholls LG, Harris AL, Stratford IJ, Hankinson O, Pugh CW, Ratcliffe PJ (1997) Hypoxiainducible factor-1 modulates gene expression in solid tumors and influences both angiogenesis and tumor growth. Proc Natl Acad Sci USA 94:8104-8109

5. Maxwell PH, Wiesener MS, Chang GW, Clifford SC, Vaux EC, Cockman ME, Wykoff CC, Pugh CW, Maher ER, Ratcliffe PJ
(1999) The tumour suppressor protein VHL targets hypoxiainducible factors for oxygen-dependent proteolysis. Nature 399:271-275

6. Stebbins CE, Kaelin WG Jr, Pavletich NP (1999) Structure of the VHL-ElonginC-ElonginB complex: implications for VHL tumor suppressor function. Science 284:455-461

7. Kondo K, Klco J, Nakamura E, Lechpammer M, Kaelin WG Jr (2002) Inhibition of HIF is necessary for tumor suppression by the von Hippel-Lindau protein. Cancer Cell 1:237-246

8. Ivan M, Kondo K, Yang H, Kim W, Valiando J, Ohh M, Salic A, Asara JM, Lane WS, Kaelin WG Jr (2001) HIFalpha targeted for VHL-mediated destruction by proline hydroxylation: implications for O2 sensing. Science 292:464-468

9. Iliopoulos O, Levy AP, Jiang C, Kaelin WG Jr, Goldberg MA (1996) Negative regulation of hypoxia-inducible genes by the von Hippel-Lindau protein. Proc Natl Acad Sci USA 93:10595-10599

10. Ohh M, Park CW, Ivan M, Hoffman MA, Kim TY, Huang LE, Pavletich N, Chau V, Kaelin WG (2000) Ubiquitination of hypoxiainducible factor requires direct binding to the beta-domain of the von Hippel-Lindau protein. Nat Cell Biol 2:423-427

11. Feng S, Bowden N, Fragiadaki M, Souilhol C, Hsiao S, Mahmoud M, Allen S, Pirri D, Ayllon BT, Akhtar S, Thompson AAR, Jo H, Weber C, Ridger V, Schober A, Evans PC (2017) Mechanical activation of hypoxia-inducible factor 1alpha drives endothelial dysfunction at atheroprone sites. Arterioscler Thromb Vasc Biol 37:2087-2101

12. Barben M, Ail D, Storti F, Klee K, Schori C, Samardzija M, Michalakis S, Biel M, Meneau I, Blaser F, Barthelmes D, Grimm C (2018) Hif1a inactivation rescues photoreceptor degeneration induced by a chronic hypoxia-like stress. Cell Death Differ 25:2071-2085

13. Harmsen MJ, Wong CFC, Mijatovic V, Griffioen AW, Groenman F, Hehenkamp WJK, Huirne JAF (2019) Role of angiogenesis in adenomyosis-associated abnormal uterine bleeding and subfertility: a systematic review. Hum Reprod Update 25:647-671

14. Serocki M, Bartoszewska S, Janaszak-Jasiecka A, Ochocka RJ, Collawn JF, Bartoszewski R (2018) miRNAs regulate the HIF switch during hypoxia: a novel therapeutic target. Angiogenesis 21:183-202

15. Thirusangu P, Vigneshwaran V, Prashanth T, Vijay Avin BR, Malojirao VH, Rakesh H, Khanum SA, Mahmood R, Prabhakar BT (2017) BP-1T, an antiangiogenic benzophenone-thiazole pharmacophore, counteracts HIF-1 signalling through p53/MDM2mediated HIF-1alpha proteasomal degradation. Angiogenesis 20:55-71

16. Nowak-Sliwinska P, van Beijnum JR, Huijbers EJM, Gasull PC, Mans L, Bex A, Griffioen AW (2019) Oncofoetal insulin receptor isoform A marks the tumour endothelium; an underestimated pathway during tumour angiogenesis and angiostatic treatment. Br J Cancer 120:218-228

17. Reguera-Nunez E, Man S, Xu P, Kerbel RS (2018) Preclinical impact of high dose intermittent antiangiogenic tyrosine kinase inhibitor pazopanib in intrinsically resistant tumor models. Angiogenesis 21:793-804

Publisher's Note Springer Nature remains neutral with regard to jurisdictional claims in published maps and institutional affiliations. 